\title{
The Global Infectious Diseases Epidemic Information Monitoring System: Development and Usability Study of an Effective Tool for Travel Health Management in China
}

Dayong $\mathrm{Gu}^{{ }^{*}}$, MD; Jianan $\mathrm{He}^{2,3 *}$, PhD; Jie Sun ${ }^{2,3}$, BSc; Xin Shi ${ }^{4}$, PhD; Ying Ye ${ }^{2,3}$, BSc; Zishuai Zhang ${ }^{5}$, BSc; Xiangjun Wang $^{6}$, PG; Qun Su${ }^{7}, \mathrm{MSc}$; Wenjin Yu ${ }^{7}, \mathrm{PhD}$; Xiaopeng Yuan ${ }^{8}$, PhD; Ruiling Dong ${ }^{2,3}, \mathrm{MIM}$

\footnotetext{
${ }^{1}$ Department of Laboratory Medicine, Shenzhen Second People's Hospital, The First Affiliated Hospital of Shenzhen University, Health Science Center, Shenzhen, China

${ }^{2}$ Shenzhen International Travel Health Care Center (Shenzhen Customs District Port Outpatient Clinics), Shenzhen Customs District, Shenzhen, China

${ }^{3}$ Shenzhen Academy of Inspection and Quarantine, Shenzhen Customs District, Shenzhen, China

${ }^{4}$ Business School, All Saints Campus, Manchester Metropolitan University, Manchester, United Kingdom

${ }^{5}$ Department of Statistics \& Applied Probability, National University of Singapore, Singapore, Singapore

${ }^{6}$ Harbin Institute of Technology, Shenzhen, Shenzhen, China

${ }^{7}$ Shenzhen Datathinking Corporation, Shenzhen, China

${ }^{8}$ Department of Laboratory Medicine, ZhuJiang Hospital, Southern Medical University, Guangzhou, China

*these authors contributed equally
}

\section{Corresponding Author:}

Ruiling Dong, MIM

Shenzhen International Travel Health Care Center (Shenzhen Customs District Port Outpatient Clinics)

Shenzhen Customs District

Room 406, Shenzhen Kouan Hospital, Huanggang Kouan Shenghuo Qu

Futian District

Shenzhen

China

Phone: 8615019457579

Email:1047194259@qq.com

\section{Abstract}

Background: Obtaining comprehensive epidemic information for specific global infectious diseases is crucial to travel health. However, different infectious disease information websites may have different purposes, which may lead to misunderstanding by travelers and travel health staff when making accurate epidemic control and management decisions.

Objective: The objective of this study was to develop a Global Infectious Diseases Epidemic Information Monitoring System (GIDEIMS) in order to provide comprehensive and timely global epidemic information.

Methods: Distributed web crawler and cloud agent acceleration technologies were used to automatically collect epidemic information about more than 200 infectious diseases from 26 established epidemic websites and Baidu News. Natural language processing and in-depth learning technologies have been utilized to intelligently process epidemic information collected in 28 languages. Currently, the GIDEIMS presents world epidemic information using a geographical map, including date, disease name, reported cases in different countries, and the epidemic situation in China. In order to make a practical assessment of the GIDEIMS, we compared infectious disease data collected from the GIDEIMS and other websites on July 16, 2019.

Results: Compared with the Global Incident Map and Outbreak News Today, the GIDEIMS provided more comprehensive information on human infectious diseases. The GIDEIMS is currently used in the Health Quarantine Department of Shenzhen Customs District (Shenzhen, China) and was recommended to the Health Quarantine Administrative Department of the General Administration of Customs (China) and travel health-related departments.

Conclusions: The GIDEIMS is one of the most intelligent tools that contributes to safeguarding the health of travelers, controlling infectious disease epidemics, and effectively managing public health in China.

(JMIR Public Health Surveill 2021;7(2):e24204) doi: 10.2196/24204 


\section{KEYWORDS}

infectious disease; epidemic information; travel health; global; surveillance

\section{Introduction}

In the past, when infectious disease outbreaks have occurred in certain countries, such as the Middle East Respiratory Syndrome (MERS) outbreak in South Korea in 2015, specific health examinations had to be performed on travelers from those countries upon entering China [1]. This kind of health management work at Chinese ports of entry are undertaken by travel health officers (referred to as health quarantine officers in China) from China Customs. This is one of the key approaches to preventing and controlling the transmission of infectious diseases [2].

Along with the development of global economic integration, the number of international travelers to China is gradually increasing. For instance, Shenzhen is an international metropolis in China, with an urban population of more than 10 million [3]. In 2019, approximately 242 million passengers passed through the Port of Shenzhen [4]. Travel health officers at China Customs use a temperature monitoring system and epidemiological investigation as the main detecting tools to identify infected travelers [5]. Many travelers may not be aware of their infection status while traveling [6]. Therefore, travel health officers must pay attention to the latest epidemic information regarding certain infectious diseases to determine whether these travelers may be infected and prepare the related public health materials. In general, information concerning global infectious disease outbreaks is manually collected, which is a time-consuming and error-prone process. Travel health officers require an infectious disease information collection system that can automatically collect epidemic information from a large number of websites, extract key information, and translate it into the native language. For these reasons, the Harbin Institute of Technology (Shenzhen, China) and Datathinking Corporation (Shenzhen, China) developed the Global Infectious Diseases Epidemic Information Monitoring System (GIDEIMS) in coordination with the Central Laboratory of Health Quarantine of the Shenzhen International Travel Health Care Center (Shenzhen Customs District Port Outpatient Clinics). The GIDEIMS is currently used by the Health Quarantine Department at the Port of Shenzhen Customs, and the system was recommended to the Health Quarantine Administrative Department of the General Administration of Customs (China) and travel health-related departments. An
Epidemic Information Team has been established by the General Administration of Customs (China) aimed at supporting the travel health officers and related departments in public health management. With the application of the GIDEIMS, updated and useful global infectious disease information is sent to the concerned parties daily, as well as useful information for infectious disease prevention and control, such as instructions on how to prepare public health materials, including masks and test kits. The aim of the GIDEIMS is to provide travelers and travel health staff with a helpful tool for public health management.

\section{Methods}

\section{Selection of Websites}

Web queries on infectious diseases could be one of the most accurate, cost-effective, and labour-extensive sources of syndromic surveillance [7]. Some established and/or official websites are frequently used by related staff and citizens to gain human infectious disease epidemic information. The websites used in the GIDEIMS are listed in Table 1; most infectious disease epidemic information, including information about COVID-19, can be found on these websites. Although all of these websites show excellent performance in the search and distribution of epidemic information, they are characterized by specific limitations. For instance, ProMED [8] reports on human diseases, as well as plant and animal diseases, while the Global Incident Map reports on fewer than 40 types of human infectious diseases, excluding chicken pox. Moreover, the epidemic information provided by the World Health Organization is reported by the member of states, and its distribution may be delayed. Data from different resources must be generated to obtain comprehensive information; the combined expertise of the different systems enhances performance for the early detection of infectious disease outbreaks [9]. Considering that the traditional manual search approach is time-consuming and may be inaccurate, as well as the fact that most of the existing websites are only offered in non-Chinese languages, Chinese travel health officers require a user-friendly infectious disease system that can effectively translate diverse information from multiple sources. For these purposes, we developed the GIDEIMS to provide a simple, effective, and sustainable tool for obtaining information on global human infectious disease epidemics. 
Table 1. Websites used in the Global Infectious Diseases Epidemic Information Monitoring System.

\begin{tabular}{|c|c|c|}
\hline $\begin{array}{l}\text { Website } \\
\text { number }\end{array}$ & Name and responsible department & Important column \\
\hline $1^{\mathrm{a}}$ & - $\mathrm{WHO}^{\mathrm{b}}[10]$ & - "Disease Outbreak News" \\
\hline $2^{\mathrm{a}}$ & - WHO Western Pacific Region [11] & - "Outbreaks and emergencies" in "Emergencies" \\
\hline $3^{\mathrm{a}}$ & $\begin{array}{l}\text { - WHO Regional Office for the Eastern Mediterranean } \\
{[12]}\end{array}$ & \\
\hline $4^{\mathrm{a}}$ & - WHO Regional Office for Europe [13] & - "Emergencies" from "Health topics" \\
\hline $5^{\mathrm{a}}$ & - WHO Regional Office for the Americas [14] & - Epidemiological Alerts and Updates \\
\hline $6^{\mathrm{a}}$ & - WHO Regional Office for Africa [15] & - Outbreaks and other emergencies \\
\hline $7^{\mathrm{a}}$ & - $\quad \operatorname{ECDC}^{\mathrm{c}}[16]$ & - $\quad$ News \& events \\
\hline $8^{\mathrm{a}, \mathrm{d}}$ & - $\mathrm{MOH}^{\mathrm{e}}$ (Kingdom of Saudi Arabia) [17] & - Command and control center \\
\hline $9^{\mathrm{a}, \mathrm{d}}$ & $\begin{array}{l}\text { - Travel Health Service, Department of Health, Hong } \\
\text { Kong, China [18] }\end{array}$ & - "Travel Health News" \\
\hline $10^{\mathrm{a}}$ & - $\quad \mathrm{CDC}^{\mathrm{f}}$ (US) [19] & - "Outbreaks" \\
\hline $11^{\mathrm{a}, \mathrm{d}}$ & - $\mathrm{MOH}$ (Singapore) [20] & - "Weekly Infectious Diseases Bulletin" in "disease update" \\
\hline $12^{\mathrm{a}}$ & - Global Polio Education Initiative [21] & - "This week" in "Polio Today" \\
\hline $13^{\mathrm{g}}$ & $\begin{array}{l}\text { Program for Monitoring Emerging Diseases, Inter- } \\
\text { national Society for Infectious Diseases [22] }\end{array}$ & - Need to distinguish human or animal diseases \\
\hline $14^{\mathrm{a}, \mathrm{d}}$ & $\begin{array}{l}\text { - Centre for Health Protection, Department of Health } \\
\text { (Hong Kong, China) [23] }\end{array}$ & - "Outbreaks" \\
\hline $15^{\mathrm{a}, \mathrm{d}}$ & - $\quad \mathrm{CDC}$ (South Korea) [24] & - "Domestic Infectious Disease Occurrence" from "Archives" \\
\hline $16^{\mathrm{a}, \mathrm{d}}$ & - Department of Disease Control (Thailand) [25] & - Weekly Disease Forecast \\
\hline $17^{\mathrm{g}}$ & $\begin{array}{l}\text { - Outbreak News Today, satellite of The Global Dis- } \\
\text { patch Inc [26] }\end{array}$ & - Recent posts \\
\hline $18^{\mathrm{g}}$ & - $\quad$ Global Incident Map [27] & - $\quad 50$ newest events \\
\hline $19^{\mathrm{a}}$ & - Pan American Health Organization [28] & - "Epidemiological Alerts and Updates" \\
\hline $20^{\mathrm{a}}$ & - Travel health notices, Government of Canada [29] & - "Travel health notices" \\
\hline $21^{\mathrm{g}}$ & $\begin{array}{l}\text { Center for Infectious Disease Research and Policy, } \\
\text { Academic Health Center, University of Minnesota } \\
\text { (MN, US) [30] }\end{array}$ & - "News and Perspective" \\
\hline $22^{\mathrm{a}, \mathrm{d}}$ & - $\mathrm{CDC}, \mathrm{MOH}$ (Taiwan) [31] & - Professional and public version \\
\hline $23^{\mathrm{a}, \mathrm{d}}$ & $\begin{array}{l}\text { - Unit for Communicable Disease Prevention and } \\
\text { Diseases Surveillance, CDC (Macau, China) [32] }\end{array}$ & - "latest news" \\
\hline $24^{\mathrm{a}, \mathrm{d}}$ & - $\quad$ Chinese National Influenza Center [33] & - "Weekly Report" \\
\hline $25^{\mathrm{g}}$ & - $\quad$ HealthMap, Harvard University (MA, US) [34] & - "Outbreaks Near Me" \\
\hline
\end{tabular}




\begin{tabular}{lll}
\hline $\begin{array}{l}\text { Website } \\
\text { number }\end{array}$ & Name and responsible department & Important column \\
\hline $26^{\mathrm{a}, \mathrm{d}}$ & $\bullet$ & $\begin{array}{l}\text { Nigeria Center for Disease Control and Prevention } \\
{[35]}\end{array}$
\end{tabular}

${ }^{\mathrm{a} O f f i c i a l}$ public websites.

${ }^{\mathrm{b}}$ WHO: World Health Organization.

${ }^{c}$ ECDC: European Centre for Disease Prevention and Control.

${ }^{\mathrm{d}}$ Users pay close attention to epidemic information from this area.

${ }^{\mathrm{e}} \mathrm{MOH}$ : Ministry of Health.

${ }^{\mathrm{f}} \mathrm{CDC}$ : Centers for Disease Control and Prevention.

${ }^{\mathrm{g}}$ This website gives comprehensive and timely epidemic information.

Meanwhile, several research organizations and government departments have their own information systems (eg, the Global Public Health Intelligence Network from the Public Health Agency of Canada). These websites were not used in the GIDEIMS due to their limitations or unavailability in China [36-40] (Table 2). At present, the GIDEIMS automatically

collects information concerning more than 200 infectious diseases from 26 established official epidemic websites and Baidu news [41]. Web crawlers, which are used to retrieve information from websites and can be modified according to the requirements of the user, provide an advanced technique for information searching [42].

Table 2. Established and/or official public websites not used in the Global Infectious Diseases Epidemic Information Monitoring System.

\begin{tabular}{|c|c|c|}
\hline $\begin{array}{l}\text { Website } \\
\text { number }\end{array}$ & Name and responsible department & Limitations \\
\hline 1 & - $\quad$ Medisys, The European Union [43] & $\begin{array}{l}\text { - Some information on global infectious diseases is delayed (eg, Ebola from Demo- } \\
\text { cratic Republic of the Congo). }\end{array}$ \\
\hline 2 & $\begin{array}{l}\text { - Biocaster, National Institute of Informat- } \\
\text { ics (Japan) }[7,8]\end{array}$ & - This project ran from 2012 to 2016; currently unavailable. \\
\hline 3 & - $\quad$ Epispider, $\mathrm{CDC}^{\mathrm{a}}$ (US) $[7,9]$ & - Currently unavailable from the mentioned website address and CDCa (US) websites. \\
\hline 4 & $\begin{array}{l}\text { Project Argus, Georgetown University } \\
\text { (Washington, DC, US) and MITRE Cor- } \\
\text { poration (VA, US), sponsored by the } \\
\text { Government of the US }[7,36]\end{array}$ & - Currently unavailable from the mentioned website address. \\
\hline 5 & $\begin{array}{l}\text { - The RODS }{ }^{\mathrm{b}} \text { Open Source Project, RODS } \\
\text { Library, University of Pittsburgh (PA, } \\
\text { US) [9] }\end{array}$ & $\begin{array}{l}\text { - The software requires purchasing a license, and the website has not been updated } \\
\text { since } 2009 \text {. }\end{array}$ \\
\hline 6 & $\begin{array}{l}\text { - } \quad \text { GPHIN }^{\mathrm{c}} \text {, Public Health Agency of Cana- } \\
\text { da }[36,37]\end{array}$ & $\begin{array}{l}\text { - Currently unavailable in the websites of the Public Health Agency of Canada. The } \\
\text { WHO }^{d} \text { website contains the main information collected by the GPHIN [37]. }\end{array}$ \\
\hline 7 & - $\quad$ Google Inc [44] & $\begin{array}{l}\text { - The same visitor is not allowed to visit the site frequently, Chinese government also } \\
\text { has restrictions on access to Google. }\end{array}$ \\
\hline
\end{tabular}

${ }^{\mathrm{a}} \mathrm{CDC}$ : Centers for Disease Control and Prevention.

${ }^{\mathrm{b}}$ RODS: Real-time Outbreak and Disease Surveillance.

${ }^{\mathrm{c}}$ GPHIN: Global Public Health Intelligence Network.

${ }^{\mathrm{d}}$ WHO: World Health Organization.

\section{Structure}

The GIDEIMS uses distributed web crawler $[45,46]$ and cloud acceleration technologies to automatically collect epidemic information. Natural language processing and in-depth learning technologies are used to intelligently process epidemic information collected in 28 languages. The language translation service is provided by Baidu Translate, which is recognized as

one of most reliable online translation services in China [47]. Cloud acceleration technology is used to improve work performance of the system.

Figure 1 shows the principle of the design of the GIDEIMS. In the figure, working staff refers to travel health officers; they provided the addresses/names of the epidemic information websites and requirements to the GIDEIMS administrator. The GIDEIMS administrator operated the center control mode 
according to the requirements set by the working staff. extraction, and processing operations were performed. Subsequently, a series of webpage crawling, information

Figure 1. Principle of the Global Infectious Diseases Epidemic Information Monitoring System design.

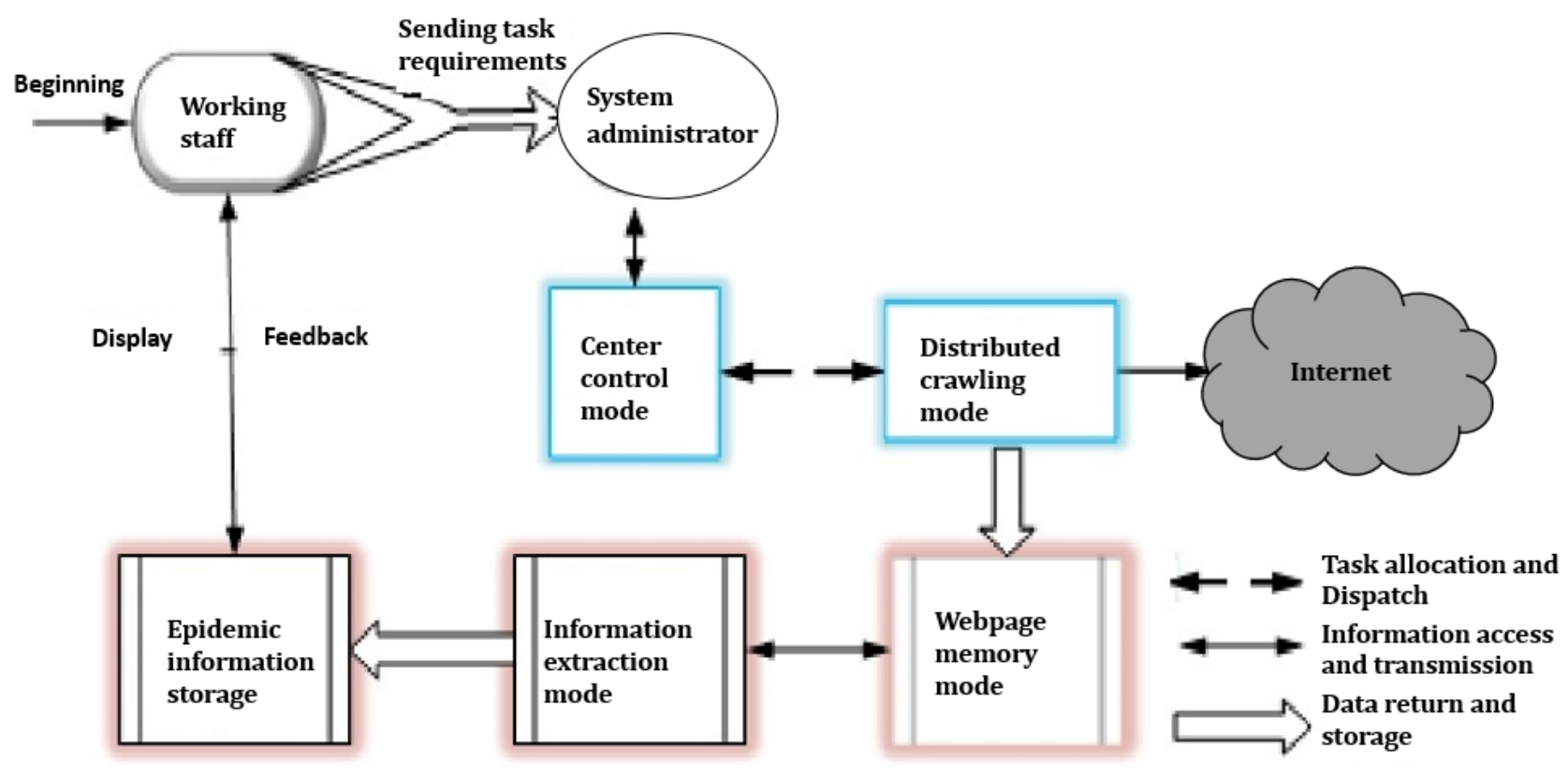

The center control mode is the core mode of the entire system. It includes the setup of the crawling strategy, assignment of tasks, and management, testing, and debugging of the system by the administrator of the GIDEIMS.

The distributed crawling mode is the execution mode of the system and the key to determining the efficiency of the entire system. In this mode, multiple crawling machines cooperate to find webpages on the internet and jointly complete the crawling task.

The main task of the webpage memory mode is to find webpages on the internet using the crawler mode and store them in a particular structure. The main task of the information extraction mode is to define extraction rules according to acquisition tasks set by the user and webpage characteristics. Moreover, this mode extracts the information available on the webpage identified by the crawler mode according to the rules and transmits the extracted results to the storage mode.

The purpose of the epidemic information storage mode is to develop a data table related to the extraction rules defined by the information extraction mode.

\section{Results}

\section{Main Functions of the GIDEIMS}

The GIDEIMS includes 7 functions: (1) GIDEIMS map, (2) latest outbreaks, (3) epidemic inquiry, (4) epidemic information entry, (5) general analysis, (6) basic setup, and (7) further functions.

\section{GIDEIMS Map}

The GIDEMS map shows the latest available information worldwide and in China. Information is acquired and shown automatically by the virtual private network.

The map has two submaps: (1) a global infectious disease epidemic map (GDM), and (2) a map of the epidemic situation in China (ESC) (Figure 2). The GDM presents the epidemic information for each country using different colors and can update the epidemic information for different countries in 3 seconds. The second map, the ESC, shows the epidemic information available for different regions of China, differentiated by color. When the mouse hovers over a region on the map, a list of the captured epidemic information from this region will be automatically displayed. By clicking on the list, users can obtain the relevant detailed information. For user interest, the map shows epidemic information by countries/regions, global today (list of global epidemic information available within the last 24 hours), latest data from China (list of domestic epidemic information available within the last month), ranking of the amount of global epidemic information available within the last month (ie, the amount of epidemic information available for each country, ranked from most to least), and an information search function.

The GIDEIMS map provides information and data services with simple interfaces and convenient operation. Travelers and travel health officers can simply identify the global human infectious disease epidemic situation at a glance. 
Figure 2. The Global Infectious Diseases Epidemic Information Monitoring System map.

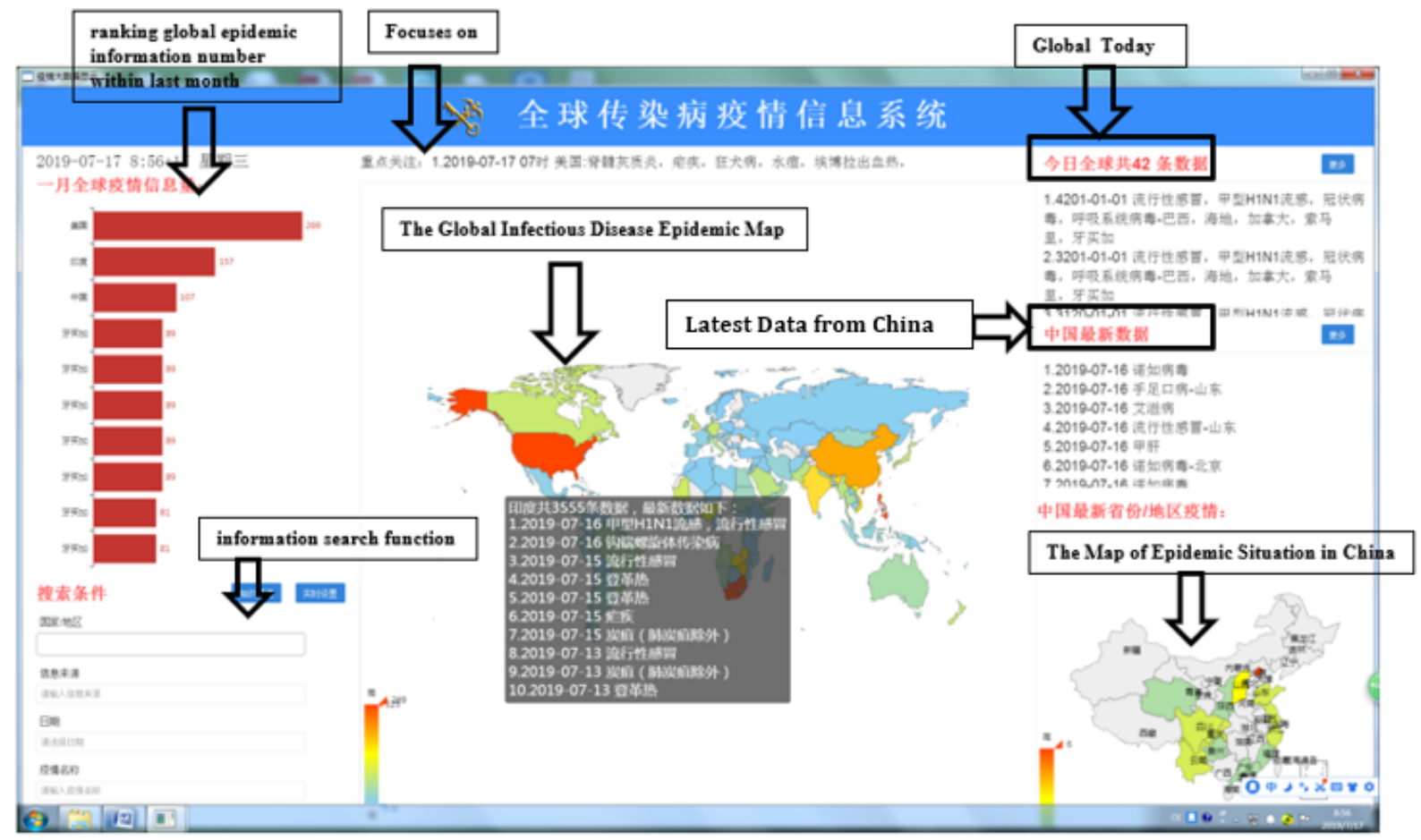

\section{Latest Outbreaks}

In the latest outbreaks part of the system, the epidemic situation over the last 48 hours is shown, and information is updated hourly. Epidemic situations can be classified based on different data source websites and different kinds of diseases. At present, this mode is updated on an hourly basis. A large amount of data is intelligently analyzed using the background cloud server to automatically search and mine infectious disease epidemic information from official epidemic websites. The GIDEIMS can intelligently extract information including name of the epidemic disease, occurrence area, and epidemic description information from the searched webpages. Subsequently, the system automatically translates the data into Chinese and displays them to the users, facilitating the understanding of the epidemic information by users. The GIDEIMS also provides links to the original webpages and web snapshots to facilitate verification.

\section{Epidemic Inquiry}

The epidemic information collected by the GIDEIMS contains the resource titles, country/area, name of the infectious disease, reported date, crawling date, information sources, number of infected cases, number of deaths, and more. Users can utilize the general inquiry function to search the aforementioned epidemic information. The query results can be displayed in the format of lists or map reports. The outbreaks in different regions and countries can be viewed at a glance.

Users can access announcements from the health administrative department. These announcements contain the main introduction of disease, epidemic information, quarantine measures for travelers, advice for travelers heading to the area of the epidemic. Chinese travel health officers should follow the regulations of the administrative department-for example, a certain country with a severe COVID-19 epidemic situation has been regarded as a focus by the administrative department, and travelers from that country should receive COVID-19-related examinations when they enter China; hence, the prompt distribution of such announcements is very important for public health management.

The epidemic inquiry function contains an "important epidemic" section showing important infectious disease epidemic information, such as quarantine diseases that the Frontier Health and Quarantine Law (China) has regulated and other important epidemic diseases. Quarantine diseases include plague, cholera, and yellow fever, as stipulated by the state council of China [48]. In 2020, the essential epidemic diseases include plague, cholera, yellow fever, influenza, polio, Zika, dengue, chikungunya, malaria, measles, West Nile fever, and COVID-19. The list of diseases may be edited by the users in the basic setup section.

Based on the requirements set by the users, the number of infected cases and deaths, as well as epidemic information for areas of interest to the users, can also be accessed.

\section{Other Functions}

Other functions of the GIDEIMS are epidemic information entry, general analysis, basic setup, and further functions.

In the epidemic information entry function, travel health staff can manually enter epidemic information. The general analysis function reports epidemic information in a user-defined manner. Basic setup includes user management, important epidemic management, and important area management. For user management, the administrator may add, edit, or delete users. 
Also, criteria such as "important epidemic" or "important area" could be adjusted based on the user's requirements.

The GIDEIMS is continuously upgraded because of many factors, such as users' needs, source websites changes, or the global epidemic situation of a certain disease. Users will be able to send epidemic information to administrative departments and be linked to defined social media.

\section{Practical Case}

In this section, we illustrate the GIDEIMS as a practical case to assess the system's functionalities. The GIDEIMS map is seen by users via an independent path (ie, a virtual private network), while the other functions of the GIDEIMS are shown as websites.

Prior to using the GIDEIMS map, users install the specific application program provided by the developer in order to view the map (Figure 2). On July 16, 2019, the GIDEIMS collected 46 pieces of data compared with 10 pieces of data provided by the Global Incident Map and 6 pieces of data provided by Outbreak News Today (see Table 3). The data included 27 types of epidemic information from 23 countries/areas (10 websites). Two pieces of data were collected by both the Global Incident Map and Outbreak News Today (numbers 8 and 10 in Table 3). 
Table 3. Epidemic information collected on July 16, 2019.

\begin{tabular}{|c|c|c|c|c|}
\hline $\begin{array}{l}\text { Data item } \\
\text { number }\end{array}$ & Country/area & Title & Disease & Resource \\
\hline 1 & $\mathrm{DRC}^{\mathrm{a}}$ & 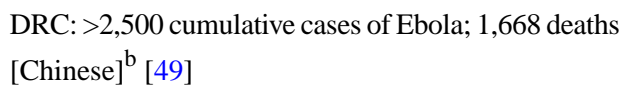 & Ebola & Baidu News \\
\hline 2 & DRC & $\begin{array}{l}\text { Fighting between DRC and Ebola has triggered the } \\
\text { first confirmed case in Goma [Chinese }{ }^{\mathrm{b}}[50]\end{array}$ & Ebola & Baidu News \\
\hline 3 & DRC & $\begin{array}{l}\text { DRC: Ebola virus disease [update] [Chinese Tradi- } \\
\text { tional] }^{\text {b }} \text { [51] }\end{array}$ & Ebola & $\begin{array}{l}\text { Travel Health Service, Department } \\
\text { of Health (Hong Kong, China) }\end{array}$ \\
\hline 4 & DRC & Measles outbreak in the DRC [Chinese] ${ }^{\mathrm{b}}[52]$ & Measles & Baidu News \\
\hline 5 & DRC & $\begin{array}{l}\mathrm{WHO}^{\mathrm{c}} \text { will take up Ebola emergency declaration } \\
\text { question for a fourth time [53] }\end{array}$ & Ebola & CIDRAP $^{\mathrm{d}}$ \\
\hline 6 & Myanmar & Swine flu death toll rises to 54 in Myanmar [54] & Influenza & Global Incident Map \\
\hline 7 & Pakistan & 54 more dengue cases surface [55] & Dengue & Global Incident Map \\
\hline 8 & Singapore & Singapore reports 666 dengue cases last week [56,57] & Dengue & $\begin{array}{l}\text { Global Incident Map; Outbreak } \\
\text { News Today }\end{array}$ \\
\hline 9 & Singapore & $\begin{array}{l}\text { Dengue cases: } 75 \text { cases notified } 16 \text { Jul } 2019 \text { at } 3 \text { pm } \\
\text { [58] }\end{array}$ & Dengue & $\begin{array}{l}\text { National Environment Agency, } \\
\text { Singapore }\end{array}$ \\
\hline 10 & Philippines & Dengue in Zamboanga up 285 percent this year [59] & Dengue & $\begin{array}{l}\text { Global Incident Map; Outbreak } \\
\text { News Today }\end{array}$ \\
\hline 11 & Cameroon & Cholera kills five in Far North region [60] & Cholera & Global Incident Map \\
\hline 12 & India & H1N1 flu on the rise, 309 cases in Mumbai [61] & Influenza & Global Incident Map \\
\hline 13 & India & Leptospirosis_-India (03): (Maharashtra) [62] & Leptospirosis & ProMED-mail \\
\hline 14 & India & Japanese encephalitis \& other-India (17): (AS) [63] & $\begin{array}{l}\text { Japanese en- } \\
\text { cephalitis }\end{array}$ & ProMED-mail \\
\hline 15 & India & $\begin{array}{l}\text { Nipah-affected student to be discharged on Tuesday } \\
\text { [64] }\end{array}$ & Nipah virus & Global Incident Map \\
\hline 16 & India & 8-year-old dies due to suspected dengue fever [65] & Dengue & Global Incident Map \\
\hline 17 & Bangladesh & Nearly 2,800 cases in first 16 days of July [66] & Dengue & Global Incident Map \\
\hline 18 & Canada & $\begin{array}{l}\text { Canada: 1st human rabies case reported since } 2012 \\
\text { [67] }\end{array}$ & Rabies & Outbreak News Today \\
\hline 19 & Canada & Canada: Syphilis outbreak in Alberta [68] & Syphilis & Outbreak News Today \\
\hline 20 & United States & $\begin{array}{l}\text { Cryptosporidium in the US with Joseph Eisenberg, } \\
\mathrm{PhD} \text { [69] }\end{array}$ & $\begin{array}{l}\text { Cryptosporidio- } \\
\text { sis }\end{array}$ & Outbreak News Today \\
\hline 21 & United States & $\begin{array}{l}\text { Anthrax in Texas update: Eight premises in three } \\
\text { counties [70] }\end{array}$ & Anthrax & Outbreak News Today \\
\hline 22 & United States & $\begin{array}{l}\text { Florida reports } 1,900 \text { hepatitis A cases so far, Pasco } \\
\text { County has seen the most [71] }\end{array}$ & Hepatitis A & Outbreak News Today \\
\hline 23 & United States & Angiostrongylus cantonensis-US (04): (HI) [72] & $\begin{array}{l}\text { Angiostrongylia- } \\
\text { sis }\end{array}$ & ProMED-mail \\
\hline 24 & United States & Infant botulism—US (02): (TX) more cases [73] & Botulism & ProMED-mail \\
\hline 25 & United States & $\begin{array}{l}\text { Undiagnosed respiratory illness-US (02): (VA) fa- } \\
\text { tal, retirement community [74] }\end{array}$ & Undiagnosed & ProMED-mail \\
\hline 26 & United States & El Paso reports 3rd measles case [75] & Measles & Outbreak News Today \\
\hline 27 & United States & $\begin{array}{l}\text { Rise in Candida auris cases; New AMR plan in Wales } \\
\text { [76] }\end{array}$ & Candida auris & CIDRAP $^{\mathrm{d}}$ \\
\hline 28 & Malaysia & Malaria_Malaysia: Pahang, resurgence [77] & Malaria & ProMED-mail \\
\hline 29 & Saudi Arabia & MERS-CoV (57): Saudi Arabia (NJ,RI) WHO [78] & MERS ${ }^{\mathrm{e}}$ & ProMED-mail \\
\hline
\end{tabular}




\begin{tabular}{|c|c|c|c|c|}
\hline $\begin{array}{l}\text { Data item } \\
\text { number }\end{array}$ & Country/area & Title & Disease & Resource \\
\hline 30 & Saudi Arabia & $\begin{array}{l}\text { WHO notes clusters in recent MERS cases, unveils } \\
\text { environmental sampling guide [79] }\end{array}$ & MERS & CIDRAP \\
\hline 31 & France & Salmonellosis_France: cured ham, alert, recall [80] & Salmonellosis & ProMED-mail \\
\hline 32 & Syria & $\begin{array}{l}\text { Brucellosis—Syria: (Quneitra) increasing incidence } \\
\text { [Arabic] }^{\mathrm{b}}[81]\end{array}$ & Brucellosis & ProMED-mail \\
\hline 33 & Kenya & Anthrax-Kenya (12): (KU) human, cattle [82] & Anthrax & ProMED-mail \\
\hline 34 & Taiwan & $\begin{array}{l}\text { One newly diagnosed case of local dengue fever in } \\
\text { Tainan [Chinese Traditional] }{ }^{\mathrm{b}}[83]\end{array}$ & Dengue & Taiwan $\mathrm{CDC}^{\mathrm{f}}$ \\
\hline 35 & Taiwan & $\begin{array}{l}\text { A new case of enterovirus complicated with severe } \\
\text { illness [Chinese Traditional] }]^{\mathrm{b}}[84]\end{array}$ & $\begin{array}{l}\text { Hand, foot and } \\
\text { mouth disease }\end{array}$ & Taiwan CDC \\
\hline 36 & $\begin{array}{l}\text { Brazil, Cambodia, Pak- } \\
\text { istan, etc }\end{array}$ & $\begin{array}{l}\text { Dengue fever or Chikungunya fever are prevalent in } \\
\text { many countries in the world [Chinese Traditional] } \\
\text { [85] }\end{array}$ & $\begin{array}{l}\text { Dengue, } \\
\text { chikungunya }\end{array}$ & Taiwan CDC \\
\hline 37 & Europe & Rising European measles vaccination [86] & Measles & CIDRAP \\
\hline 38 & Thailand & $\begin{array}{l}\text { The disease control department recently revealed that } \\
\text { the situation of dengue fever is slowing down [Thai }{ }^{\mathrm{b}} \\
\text { [87] }\end{array}$ & Dengue fever & $\begin{array}{l}\text { The Department of Disease Con- } \\
\text { trol of Thailand }\end{array}$ \\
\hline 39 & Nigeria & $\begin{array}{l}\text { An update of Lassa fever outbreak in Nigeria for } \\
\text { Week } 27 \text { [88] }\end{array}$ & Lassa fever & Nigeria CDC \\
\hline 40 & Nigeria & $\begin{array}{l}\text { An update of Cholera outbreak in Nigeria for Week } \\
27 \text { [89] }\end{array}$ & Cholera & Nigeria CDC \\
\hline 41 & Namibia & H1N1 claims life in Windhoek [90] & Influenza & Global Incident Map \\
\hline 42 & China & $\begin{array}{l}\text { The reported incidence of hepatitis A and B in Gansu } \\
\text { Province was significantly reduced [Chinese }]^{\mathrm{b}}[91]\end{array}$ & $\begin{array}{l}\text { Hepatitis A and } \\
\text { B }\end{array}$ & Baidu News \\
\hline 43 & China & $\begin{array}{l}\text { Foodborne illness-China: Beijing, tap water, } \\
\text { norovirus suspected [92] }\end{array}$ & Norovirus & ProMED-mail \\
\hline 44 & China & $\begin{array}{l}\text { Suspected Norovirus Infection in Residents of Wanke } \\
\text { Qingqing Home District, Chaoyang, Beijing [Chi- } \\
\text { nese] }^{b} \text { [93] }\end{array}$ & Norovirus & Baidu News \\
\hline 45 & China & $\begin{array}{l}\text { Shandong: In June, fewer people got the flu than } \\
\text { those infected with hand, foot, and mouth disease } \\
\text { [Chinese }]^{\mathrm{b}}[94]\end{array}$ & $\begin{array}{l}\text { Hand, foot, and } \\
\text { mouth disease }\end{array}$ & Baidu News \\
\hline 46 & Global & $\begin{array}{l}\text { The latest report issued by UNAIDS: the mixed situ- } \\
\text { ation of countries [Chinese] }{ }^{b}[95]\end{array}$ & HIV & Baidu News \\
\hline
\end{tabular}

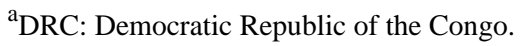

${ }^{\mathrm{b}}$ Translated by Baidu Translate.

${ }^{c}$ WHO: World Health Organization.

${ }^{\mathrm{d}}$ CIDRAP: Center for Infectious Disease Research and Policy.

${ }^{\mathrm{e}}$ MERS: Middle East Respiratory Syndrome.

${ }^{\mathrm{f}} \mathrm{CDC}$ : Centres for Disease Control and Prevention.

For the other functions of the GIDEIMS, first, the user must access the system using a defined website address [96]. After entering the username and password, the user sees the latest outbreak page (Figure 3), which shows the last five pieces of epidemic information news from each website. By clicking the "more" button, the user gains access to further epidemic information. The "check" button displays the detailed information (Figure 4). Users can click the "original webpage link" to verify the information.
Users wishing to search, for example, for recent Zika epidemic information would click "Epidemic inquiry," followed by "General inquiry," enter the epidemic disease name "Zika (in Chinese)" in "Epidemic situation name," and limit the occurrence date to July 2019. The results are shown in Figure 5.

Shenzhen travel health officers use the epidemic information on a daily basis to guide their decision-making on infection disease epidemic management, such as identifying travelers 
with high fever and investigating their travel history. For travelers arriving from epidemic areas of certain infectious diseases, the officers will obtain a sample and test for the infectious diseases of interest if the traveler consents.

In contrast, without the GIDEIMS, staff could spend approximately 4 hours (excluding translation time) identifying the relevant epidemic information. With the use of the GIDEIMS, staff only need to access the collected data and verify them using the links and snapshots provided by the system when necessary. Working time is shortened to less than 1 hour. The information collected by the GIDEIMS is more accessible and comprehensive than that collected through the manual method.

Figure 3. First page of the Global Infectious Diseases Epidemic Information Monitoring System, showing the latest outbreak.

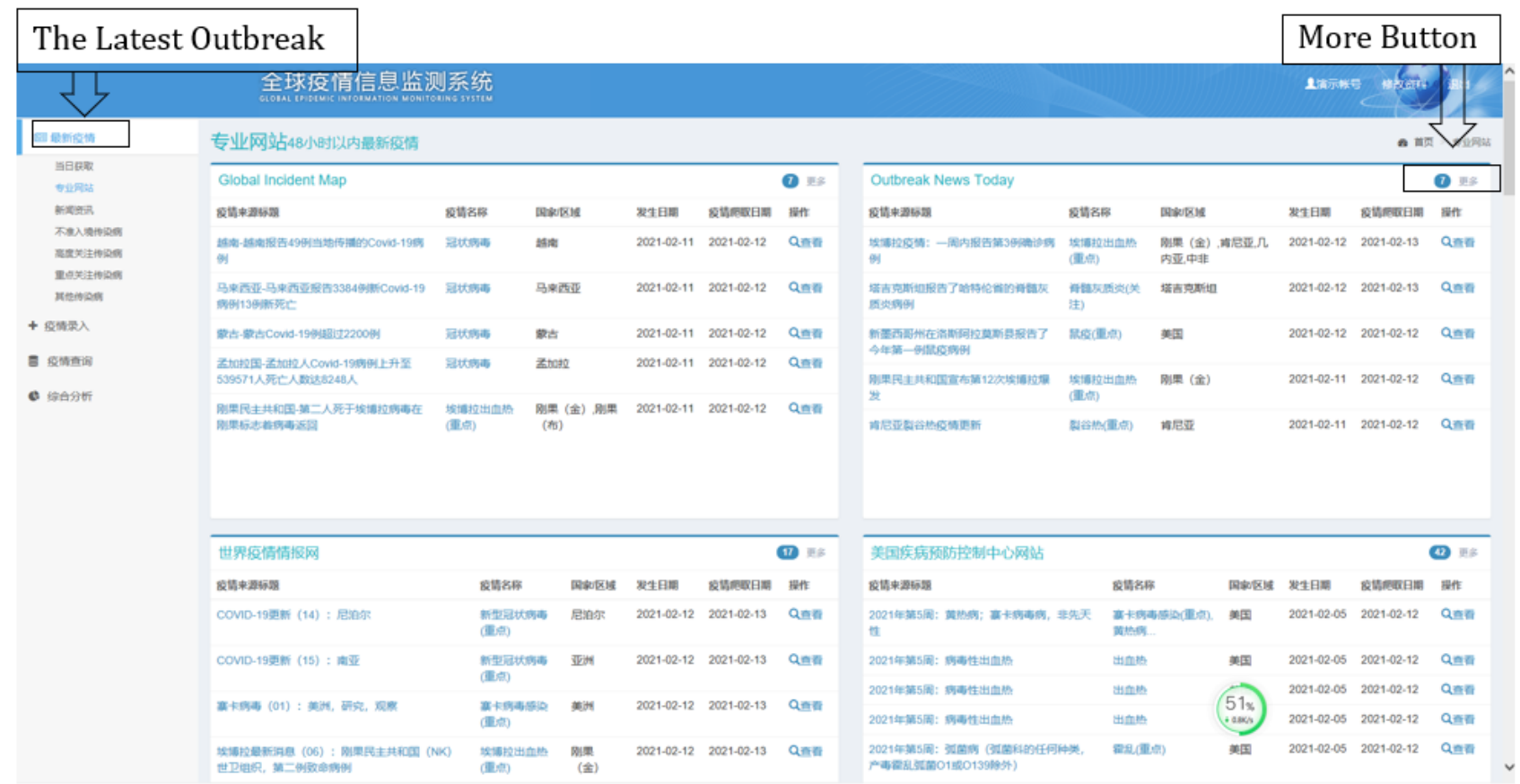

Figure 4. Detailed information provided by the Global Infectious Diseases Epidemic Information Monitoring System.

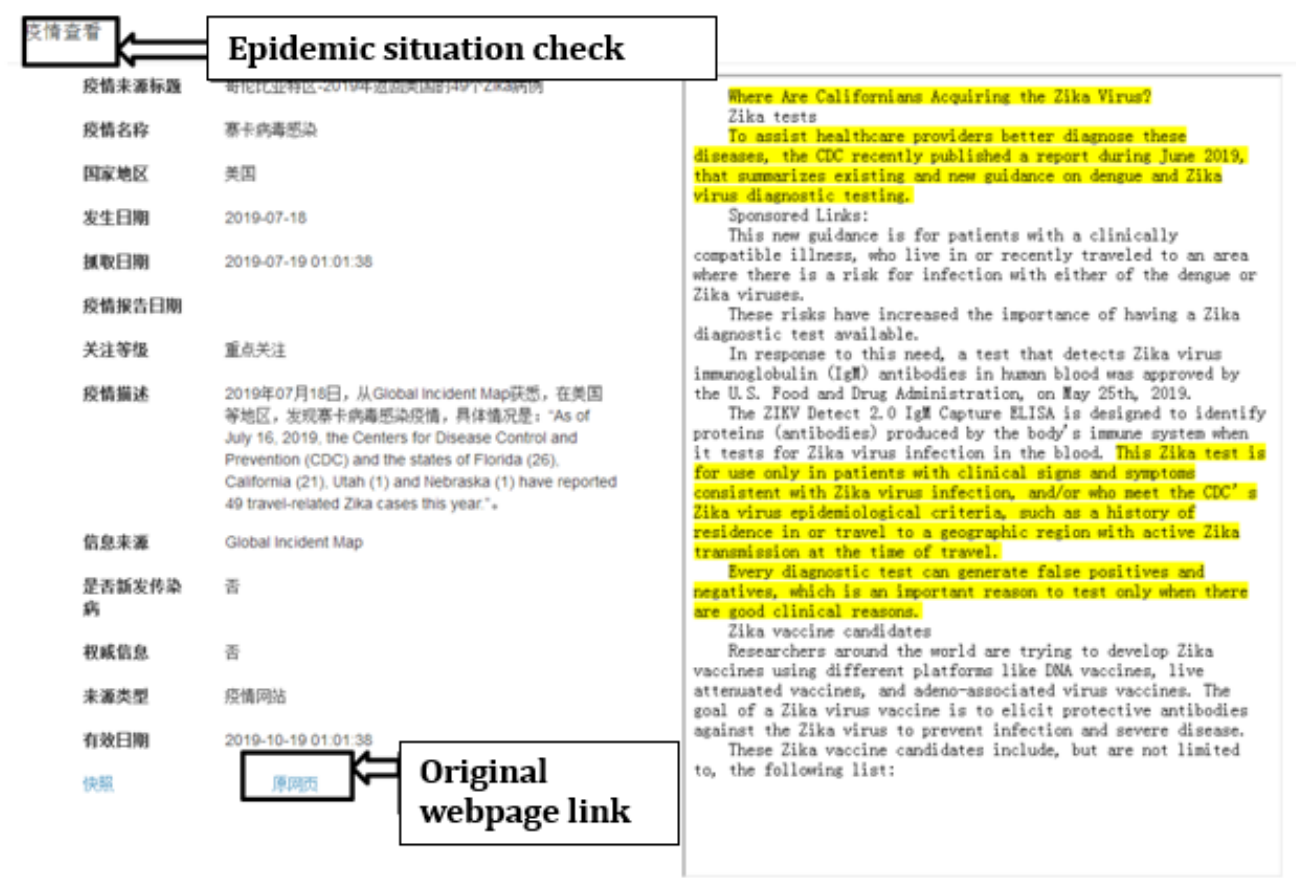


Figure 5. Sample inquiry about the Zika epidemic situation using the general inquiry function of the Global Infectious Diseases Epidemic Information Monitoring System.

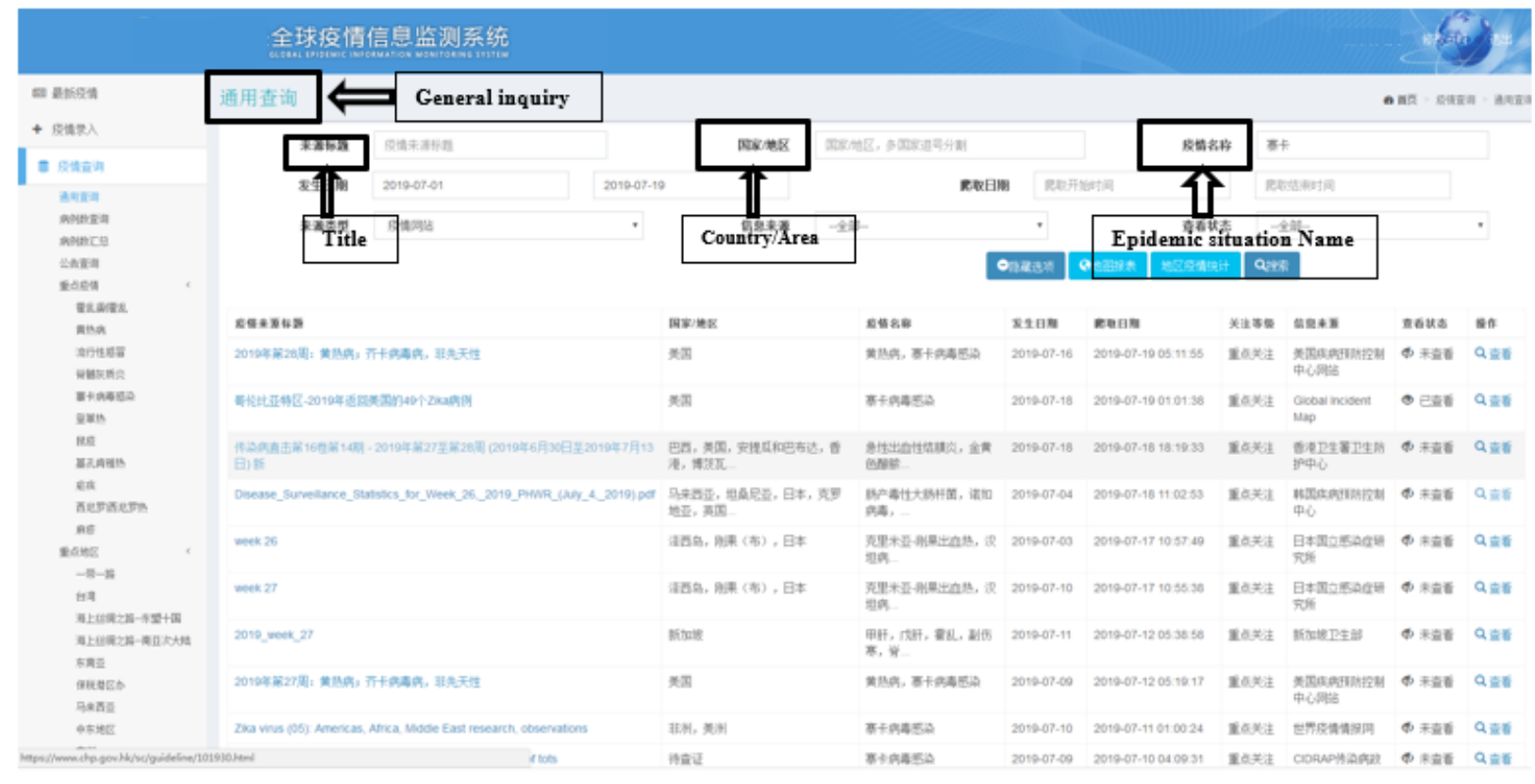

\section{Discussion}

Using the epidemic information provided by the GIDEIMS, health officers can quickly focus on travelers from certain countries and/or regions and discover infected cases as early as possible. By using the information from the GIDEIMS, staff at the Health Quarantine Center Laboratory of the Shenzhen International Travel Health Care Center (Shenzhen Customs District Port Outpatient Clinics) detected the first imported Zika cases in China [97], and thousands of suspected cases of certain infectious diseases have also been detected annually [98].Thus, while the detection work is strenuous, the GIDEIMS provides a helpful tool to effectively and sustainably identify suspected infected travelers into the Port of Shenzhen. The main advantage of the GIDEIMS is that it can automatically collect epidemic information from defined websites and translate it into the Chinese language. Although occasionally the system may duplicate information and require a manual check, most of the users of the GIDEIMS - such as the travel health officers working at Customs, travelers, researchers, and others working in the infectious disease control and prevention sector-reveal that the GIDEIMS saves time and is less labor-intensive. The first version of the GIDEIMS was developed in 2016 [99]. It is constantly upgraded to fulfill the requirements of users and adjusted according to actual situations. We constructed a visual display platform for the global infectious diseases epidemic information. The GIDEIMS is a user-friendly tool to support both travelers and travel health officers in travel health management. Meanwhile, big data obtained from the GIDEIMS may be used for infectious disease surveillance management and control.
In regard to COVID-19, information systems have largely been built to address almost every aspect of health management, including infection situation data management, remote health care system management, and syndromic surveillance [100-102]. In comparison, the GIDEIMS provides more comprehensive disease information than other COVID-19 epidemic information systems. Compared with the geographic information system for global monitoring of COVID-19 established by Johns Hopkins University [103], whose initial data were collected from the World Health Organization (WHO), US Centers for Disease Control and Prevention (CDC), China CDC, European Centre for Disease Prevention and Control (ECDC), National Health Commission of China (NHC), and DXY (a Chinese health-focused social website), the GIDEIMS could provide a full picture of the worldwide situation of the COVID-19 epidemic.

GIDEIMS breaks the barriers of language, region, time difference, and more so that it can provide enormous amounts of real-time infectious disease-related information. The system is not targeted on the individual traveler, but it provides travelers with useful information on the epidemic situation of infectious diseases.

At present, the GIDEIMS is a nonprofit application information system, where the maintenance and upgrade operations are performed by the developers free of charge. Due to the limitations of funds and human resources, the system is available in Chinese only. It is mainly provided to relevant infectious disease prevention and control departments and personnel for a free trial. 


\section{Acknowledgments}

The authors would like to thank the Health and Quarantine Office of Shenzhen Customs for its advice and comments for the improvement of the GIDEIMS.

This research was supported by the National Key Research and Development Program of China (No. 2018YFC0809200, No. 2016YFF0203203); the National Natural Science Foundation of China (No. 81703271); Guangdong Science and Technology Foundation (No. 2017B020210006, No. 2016A020219005); Shenzhen Science and Technology Foundation (No. SGLH20180625171602058, CKCY20170720100145297, No. JCYJ20160427151920801, No. JCYJ20170307104024209), and the Open Project of Key Laboratory of Tropical Disease Control of the Ministry of Education (Sun Yat-sen University, No. 2019kfkt06).

The funding sources played no role in the study design, data collection and analysis, decision to publish, or preparation of the manuscript.

\section{Authors' Contributions}

All authors participated in designing the study, analyzing the results, and writing the manuscript. All authors approved the final manuscript.

\section{Conflicts of Interest}

None declared.

\section{References}

1. Jack A. Why the panic? South Korea's MERS response questioned. BMJ 2015 Jun 24;350:h3403. [doi: 10.1136/bmj.h3403] [Medline: 26108610]

2. Barbisch D, Koenig KL, Shih FFY. Is There a Case for Quarantine? Perspectives from SARS to Ebola. Disaster Medicine and Public Health Preparedness 2015 Oct;9(5):547-553. [doi: 10.1017/dmp.2015.38] [Medline: 25797363]

3. Shenzhen 2019 GDP up 6.7\%. Shenzhen Government Online.: Shenzhen Daily URL: http://www.sz.gov.cn/en_szgov/news/ latest/content/post 7149127.html [accessed 2020-04-21]

4. Shenzhen clears 660,000 entry-exit passengers daily in 2019. Xinhuanet. URL: http://www.xinhuanet.com/english/2020-01/ 15/c 138706890.htm [accessed 2020-01-15]

5. Jiwen Z, Jin X, Zhaoyin Z, Huang L, Liang S, Xu Y, et al. Early detection of Zika virus infection among travellers from areas of ongoing transmission in China. Journal of Travel Medicine 2016;23(5). [doi: 10.1093/jtm/taw047]

6. Bo L, Zhengliang L, Bo S, Zong D, Qinlan L, Qian W, et al. Sensitive HIV-1 detection in a homogeneous solution based on an electrochemical molecular beacon coupled with a nafion-graphene composite film modified screen-printed carbon electrode. Biosensors \& Bioelectronics 2014 Feb 15;52C:330-336. [doi: 10.1016/j.bios.2013.09.016] [Medline: 24099877]

7. Anette H, Gustaf R, Annika L. Web queries as a source for syndromic surveillance. PLoS One 2009;4(2):e4378 [FREE Full text] [doi: 10.1371/journal.pone.0004378] [Medline: 19197389]

8. Malwina C, Lawrence C M. ProMED-mail: 22 years of digital surveillance of emerging infectious diseases. International Health 2017 May 01;9(3):177-183 [FREE Full text] [doi: 10.1093/inthealth/ihx014] [Medline: 28582558]

9. Philippe B, Laetitia V, Yann Le S, David M H, Noele P N, Abla M, et al. Factors influencing performance of internet-based biosurveillance systems used in epidemic intelligence for early detection of infectious diseases outbreaks. PLoS One 2014;9(3):e90536 [FREE Full text] [doi: 10.1371/journal.pone.0090536] [Medline: 24599062]

10. World Health Organization. URL: http://www.who.int/en/ [accessed 2019-07-12]

11. World Health Organization Western Pacific Region. URL: https://www.who.int/westernpacific/ [accessed 2019-07-12]

12. World Health Organization Regional Office for the Eastern Mediterranean. URL: http://www.emro.who.int/index.html [accessed 2019-07-12]

13. World Health Organization Regional Office for Europe. URL: http://www.euro.who.int/en/home [accessed 2019-07-12]

14. World Health Organization Regional Office for the Americas. URL: https://www.paho.org/hq/index.php?lang=en [accessed 2019-07-12]

15. World Health Organization Regional Office for Africa. URL: https://www.afro.who.int/ [accessed 2019-07-12]

16. European Centre for Disease Prevention and Control. URL: https://ecdc.europa.eu/en/home [accessed 2019-07-12]

17. Ministry of Health, Kingdom of Saudi Arabia. URL: https://www.moh.gov.sa [accessed 2019-07-12]

18. Travel Health Service, Department of Health, Hong Kong, China. URL: https://www.travelhealth.gov.hk [accessed 2019-07-12]

19. Centre for Disease Control and Prevention, USA. URL: https://www.cdc.gov/ [accessed 2019-07-12]

20. Ministry of Health, Singapore. URL: https://www.moh.gov.sg/ [accessed 2019-07-12]

21. Global Polio Education Initiative. URL: http://polioeradication.org/polio-today/polio-now/ [accessed 2019-07-12]

22. Program for Monitoring Emerging Diseases, International Society for Infectious Diseases. URL: http://www.promedmail.org/ [accessed 2019-07-12] 
23. Centre for Health Protection, Department of Health, Hong Kong, China. URL: https://www.chp.gov.hk/ [accessed 2019-07-12]

24. Centre for Disease Control and Prevention, South Korea. URL: http://www.cdc.go.kr/CDC/eng/main.jsp [accessed 2019-07-12]

25. Department of Disease Control, Thailand. URL: http://o.ddc.moph.go.th/eng/index.php [accessed 2019-07-12]

26. Outbreak News Today, satellite of The Global Dispatch Inc. URL: http://outbreaknewstoday.com/ [accessed 2019-07-12]

27. Global incident map. URL: http://outbreaks.globalincidentmap.com/home.php [accessed 2019-07-12]

28. Pan American Health Organization. URL: http://www.paho.org/hq/ [accessed 2019-07-12]

29. Government of Canada. URL: https://travel.gc.ca/travelling/health-safety/travel-health-notices/ [accessed 2019-07-12]

30. Center for Infectious Disease Research and Policy, Academic Health Center, University of Minnesota, MN, USA. URL: http://www.cidrap.umn.edu/news-perspective [accessed 2019-07-12]

31. Centre for Disease Control and Prevention, Ministry of Health, Taiwan. URL: http://www.cdc.gov.tw [accessed 2019-07-12]

32. Unit for Communicable Disease PreventionDiseases Surveillance, CDC, Macau, China. URL: https://www.ssm.gov.mo/ portal/ [accessed 2019-07-12]

33. Chinese National Influenza Center. URL: http://www.chinaivdc.cn/cnic/zyzx/ [accessed 2019-07-12]

34. HealthMap, Harvard University, MA, USA. URL: https://www.healthmap.org/ [accessed 2019-07-12]

35. Nigeria Center for Disease Control and Prevention. URL: https://ncdc.gov.ng/ [accessed 2019-07-12]

36. Collier N, Doan S, Kawazoe A, Goodwin RM, Conway M, Tateno Y, et al. BioCaster: detecting public health rumors with a Web-based text mining system. Bioinformatics 2008 Dec 15;24(24):2940-2941 [FREE Full text] [doi: 10.1093/bioinformatics/btn534] [Medline: 18922806]

37. Hung Quoc N. The Use of the BioCaster Ontology for Mapping Infectious Diseases and Locations in the BioCaster Surveillance System. 2018 Jan 15 Presented at: BioLINK; January 2008; Canada URL: https://www.researchgate.net/profile/ Hung_Ngo3/publication/

259290195 The Use of the BioCaster Ontology for Mapping Infectious Diseases and Locations in the BioCaster Surveillance System/ links/0deec52ac62fcc1b21000000.pdf [doi: 10.1038/npre.2008.2110.1]

38. Keller M, Blench M, Tolentino H, Freifeld CC, Mandl KD, Mawudeku A, et al. Use of unstructured event-based reports for global infectious disease surveillance. Emerg Infect Dis 2009 May;15(5):689-695 [FREE Full text] [doi: 10.3201/eid1505.081114] [Medline: 19402953]

39. Xuemei S, Qiang C, Ming W, Lin H. The Present Status and Thought on Network-media-based Information Resources of Disease Outbreak and Surveillance. Yi Xue Xin Xi Xue Za Zhi 2013;30(4):1-5 [FREE Full text] [doi: $10.18352 /$ bmgn-lchr.5703]

40. Office of Audit and Evaluation, Health Canada and the Public Health Agency of Canada. Evaluation of Emergency Preparedness and Response Activities 2012-13 to 2016-17, 4.4.2. Government of Canada. 2018. URL: https://www.canada.ca/ en/public-health/corporate/transparency/corporate-management-reporting/evaluation/

2012-2013-2016-2017-evaluation-report-emergency-preparedness-response-activities.html [accessed 2018-03-20]

41. Baidu news. URL: news.baidu.com [accessed 2021-02-07]

42. S.R. S, Sangita C. Review of web crawlers. International Journal of Knowledge \& Web Intelligence 2014;5(1):49. [doi: 10.1504/IJKWI.2014.065035]

43. Medisys, The European Union. URL: http://medisys.newsbrief.eu/medisys/helsinkiedition/zh/home.html [accessed 2019-07-12]

44. Google Inc. URL: www.google.com [accessed 2019-07-12]

45. Shuai W, Guomin Z, Jian W. Reviews of Relevance Algorithm in Focused Crawler. JI SUAN JI YU XIAN DAI HUA 2009;30(2):27-30 [FREE Full text] [doi: 10.3969/j.issn.1006-2475.2013.04.007]

46. Jiang Y. Efficiency bottlenecks analysis and solution of Web crawler. Journal of Computer Applications 2008 Oct 21;28(5):1114-1116 [FREE Full text] [doi: 10.3724/SP.J.1087.2008.01114]

47. Zhongjun H. Baidu Translate: Research and Products. 2015 Presented at: Proceedings of the Fourth Workshop on Hybrid Approaches to Translation (HyTra); 2015; Beijing. [doi: 10.18653/v1/w15-4110]

48. Standing Committee of National People's Congress of P.R.China. Frontier Health and Quarantine Law of the P.R China. China.org.cn. URL: http://www.china.org.cn/english/travel/40418.htm [accessed 2019-07-16]

49. Sina Corporation. URL: http://news.sina.com.cn/w/2019-07-16/doc-ihytcitm2491479.shtml [accessed 2019-07-16]

50. www.gangaonet.com. URL: http://www.gangaonet.com/zhusanjiao/2019/0716/116143.html [accessed 2019-07-16]

51. Travel Health Service, Department of Health, Hong Kong, China. URL: https://www.travelhealth.gov.hk/sc chi/outbreaknews/ 2019/ond09July2019.html [accessed 2019-07-16]

52. cnBeta.com. URL: http://www.cnbeta.com/articles/science/868281.htm [accessed 2019-07-16]

53. Center for Infectious Disease Research and Policy. URL: http://www.cidrap.umn.edu/news-perspective/2019/07/ who-will-take-ebola-emergency-declaration-question-fourth-time [accessed 2019-07-16]

54. Global Incident Map. URL: http://outbreaks.globalincidentmap.com/eventdetail.php?ID=32264 [accessed 2019-07-16]

55. Global Incident Map. URL: http://outbreaks.globalincidentmap.com/eventdetail.php?ID=32261 [accessed 2019-07-16]

56. Global Incident Map. URL: http://outbreaks.globalincidentmap.com/eventdetail.php?ID=32260 [accessed 2019-07-16] 
57. Outbreak News Today. URL: http://outbreaknewstoday.com/

singapore-reports-666-dengue-cases-last-week-highest-weekly-total-in-3-1-2-years-76821/ [accessed 2019-07-16]

58. National Environment Agency, Singapore. URL: http://www.nea.gov.sg/ [accessed 2019-07-16]

59. Outbreak News Today. URL: http://outbreaknewstoday.com/dengue-in-zamboanga-up-285-percent-this-year-28038/ [accessed 2019-07-16]

60. Global Incident Map. URL: http://outbreaks.globalincidentmap.com/eventdetail.php?ID=32258 [accessed 2019-07-16]

61. Global Incident Map. URL: http://outbreaks.globalincidentmap.com/eventdetail.php?ID=32257 [accessed 2019-07-16]

62. ProMED-mail. URL: http://www.promedmail.org/ajax/getPost.php?alert id=6569127 [accessed 2019-07-16]

63. ProMED-mail. URL: https://promedmail.org/promed-post/?id=6570013 [accessed 2019-07-16]

64. Global Incident Map. URL: http://outbreaks.globalincidentmap.com/eventdetail.php?ID=32296 [accessed 2019-07-16]

65. Global Incident Map. URL: http://outbreaks.globalincidentmap.com/eventdetail.php?ID=32281 [accessed 2019-07-16]

66. Global Incident Map. URL: http://outbreaks.globalincidentmap.com/eventdetail.php?ID=32270 [accessed 2019-07-16]

67. Outbreak News Today. URL: http://outbreaknewstoday.com/canada-1st-human-rabies-case-reported-since-2012/ [accessed 2019-07-16]

68. Outbreak News Today. URL: http://outbreaknewstoday.com/canada-syphilis-outbreak-in-alberta-89874/ [accessed 2019-07-16]

69. Outbreak News Today. URL: http://outbreaknewstoday.com/cryptosporidium-in-the-us-with-joseph-eisenberg-ph-d-80144/ [accessed 2015-07-16]

70. Outbreak News Today. URL: http://outbreaknewstoday.com/anthrax-in-texas-update-eight-premises-in-three-counties-84701/ [accessed 2019-07-16]

71. Outbreak News Today. URL: http://outbreaknewstoday.com/ florida-reports-1900-hepatitis-a-cases-so-far-pasco-county-has-seen-the-most-83585/ [accessed 2019-07-15]

72. ProMED-mail. URL: https://promedmail.org/promed-post/?id=6570547 [accessed 2019-07-15]

73. ProMED-mail. URL: https://promedmail.org/promed-post/?id=6571003 [accessed 2019-07-15]

74. ProMED-mail. URL: https://promedmail.org/promed-post/?id=6570174 [accessed 2019-07-15]

75. Outbreak News Today. URL: http://outbreaknewstoday.com/el-paso-reports-3rd-measles-case-48365/ [accessed 2019-07-16]

76. Center for Infectious Disease Research and Policy. URL: https://www.cidrap.umn.edu/news-perspective/2019/07/ stewardship-resistance-scan-jul-16-2019 [accessed 2019-07-16]

77. ProMED-mail. URL: https://promedmail.org/promed-post/?id=6571569 [accessed 2019-07-16]

78. ProMED-mail. URL: https://promedmail.org/promed-post/?id=6571651 [accessed 2019-07-16]

79. Center for Infectious Disease Research and Policy. URL: http://www.cidrap.umn.edu/news-perspective/2019/07/ who-notes-clusters-recent-mers-cases-unveils-environmental-sampling-guide [accessed 2019-07-16]

80. ProMED-mail. URL: https://promedmail.org/promed-post/?id=6569722 [accessed 2019-07-16]

81. ProMED-mail. URL: http://www.promedmail.org/ajax/getPost.php?alert_id=6568527 [accessed 2019-07-16]

82. ProMED-mail. URL: https://promedmail.org/promed-post/?id=6569704 [accessed 2019-07-16]

83. Taiwan Centers for Disease Control. URL: https://www.cdc.gov.tw/Bulletin/Detail/U YChDpaFYt4T2kywZjqBg?typeid=9 [accessed 2019-07-16]

84. Taiwan Centers for Disease Control. URL: https://www.cdc.gov.tw/Bulletin/Detail/GrqbboCXcIks-4mNSX8mvA?typeid=9 [accessed 2019-07-16]

85. Taiwan Centers for Disease Control. URL: https://www.cdc.gov.tw/Bulletin/Detail/qDb13SZSYwmgZ00rbAWatw?typeid=9 [accessed 2019-07-16]

86. Center for Infectious Disease Research and Policy. URL: https://www.cidrap.umn.edu/news-perspective/2019/07/ news-scan-jul-16-2019 [accessed 2019-07-16]

87. The Department of Disease Control of Thailand. URL: https://ddc.moph.go.th/th/site/newsview/view/7261 [accessed 2019-07-16]

88. Nigeria Center for Disease Control and Prevention. URL: https://ncdc.gov.ng/themes/common/files/sitreps/ a6a67b9036f6beb16adebfb11e65190f.pdf [accessed 2019-07-16]

89. Nigeria Center for Disease Control and Prevention. URL: https://ncdc.gov.ng/themes/common/files/sitreps/ 667b55aec7fb889b0b4293e79320a4ac.pdf [accessed 2019-07-16]

90. Global Incident Map. URL: http://outbreaks.globalincidentmap.com/eventdetail.php?ID=32268 [accessed 2019-07-16]

91. www.lanzhou.cn. URL: http://news.lanzhou.cn/system/2019/07/16/011794485.shtml [accessed 2019-07-16]

92. ProMED-mail. URL: http://www.promedmail.org/ajax/getPost.php?alert_id=6570349 [accessed 2019-07-16]

93. Sina Corporation. URL: http://finance.sina.com.cn/stock/relnews/cn/2019-07-16/doc-ihytcerm4014116.shtml [accessed 2019-07-16]

94. Xinhuanet. URL: http://www.sd.xinhuanet.com/news/2019-07/16/c 1124759851.htm [accessed 2019-07-16]

95. CN-Healthcare. URL: https://www.cn-healthcare.com/article/20190716/content-521492.html [accessed 2019-07-16]

96. Global Infectious Diseases Epidemic Information Monitoring System. URL: http://yq.ssdat.com:6090/quarantineSys/user/ login? returnUrl=\%2Fhome\%2Findex [accessed 2021-02-07] 
97. Chenglin D, Si-Qing L, Qiuyan Z, Mingyue X. Isolation and characterization of Zika virus imported to China using C6/36 mosquito cells. Virologica Sinica 2016;31(2):176-179 [FREE Full text] [doi: 10.1007/s12250-016-3778-5]

98. Lei S, Yang F, Yanqiu Y, Yuzhen H, Yunqing X, Dayong Gu G, et al. Epidemiological characteristics of 771 influenza cases in Shenzhen port. Zhong Guo Gong Gong Wei Sheng 2012;28(10):1352-1354 [FREE Full text] [doi: 10.11847/zgggws2012-28-10-31]

99. Xiangjun W, Chunxiao L, Muyan D, Jianan H, Dayong G, Lei S, et al. Developent of automatic collection system of global epidemic informations. Zhong Guo Guo Jing Wei Sheng Jian Yi Za Zhi 2017;40(6):431-434. [doi: 10.16408/j.1004-9770.2017.06.013]

100. Gerfalk PJ, Conboy K, Myers MD. Information systems in the age of pandemics: COVID-19 and beyond. European Journal of Information Systems 2020 Jun 14;29(3):203-207. [doi: 10.1080/0960085X.2020.1771968]

101. Hanna MG, Reuter VE, Ardon O, Kim D, Sirintrapun SJ, Schüffler PJ, et al. Validation of a digital pathology system including remote review during the COVID-19 pandemic. Mod Pathol 2020 Jun 22;33(11):2115-2127. [doi: 10.1038/S41379-020-0601-5]

102. Luo H, Lie Y, Prinzen FW. Surveillance of COVID-19 in the General Population Using an Online Questionnaire: Report From 18,161 Respondents in China. JMIR Public Health Surveillance 2020 Apr 27;6(2):e18576. [doi: 10.2196/18576]

103. Belmiro Do Nascimento J. Geographic Information Systems and COVID-19: The Johns Hopkins University DashboardJ Research Square. Research Square 2020. [doi: 10.21203/rs.3.rs-15447/v1]

\author{
Abbreviations \\ CDC: Centers for Disease Control and Prevention \\ ECDC: European Centre for Disease Prevention and Control \\ ESC: epidemic situation in China \\ GDM: global infectious disease epidemic map \\ GIDEIMS: Global Infectious Diseases Epidemic Information Monitoring System \\ MERS: Middle East Respiratory Syndrome \\ NHC: National Health Commission of China \\ WHO: World Health Organization
}

Edited by G Eysenbach; submitted 17.09.20; peer-reviewed by JM Ocampo, K Hung; comments to author 03.11.20; revised version
received 23.11.20; accepted 19.12.20; published 16.02.21
Please cite as:
Gu D, He J, Sun J, Shi X, Ye Y, Zhang Z, Wang X, Su Q, Yu W, Yuan X, Dong R
The Global Infectious Diseases Epidemic Information Monitoring System: Development and Usability Study of an Effective Tool for
Travel Health Management in China
JMIR Public Health Surveill 2021;7(2):e24204
URL: $\underline{\text { http://publichealth.jmir.org/2021/2/e24204/ }}$
doi: $\underline{10.2196 / 24204}$
PMID: $\underline{33591286}$

CDayong Gu, Jianan He, Jie Sun, Xin Shi, Ying Ye, Zishuai Zhang, Xiangjun Wang, Qun Su, Wenjin Yu, Xiaopeng Yuan, Ruiling Dong. Originally published in JMIR Public Health and Surveillance (http://publichealth.jmir.org), 16.02.2021. This is an open-access article distributed under the terms of the Creative Commons Attribution License (https://creativecommons.org/licenses/by/4.0/), which permits unrestricted use, distribution, and reproduction in any medium, provided the original work, first published in JMIR Public Health and Surveillance, is properly cited. The complete bibliographic information, a link to the original publication on http://publichealth.jmir.org, as well as this copyright and license information must be included. 